\title{
Antiplatelet Therapy in Acute Coronary Syndrome
}

\author{
Kerry Layne and Albert Ferro
}

Department of Clinical Pharmacology, Cardiovascular Division, King's College London, London, UK

\begin{abstract}
Antiplatelet agents have for decades been used to improve outcomes in patients with acute coronary syndromes and have become increasingly valued, not only for their antithrombotic properties but also for their anti-inflammatory effects. The drug class continues to evolve as novel agents with increasingly efficacious antiplatelet actions are identified. This review will discuss antiplatelet agents, including aspirin, the $\mathrm{P}_{2} \mathrm{Y}_{12}$ receptor antagonists and the glycoprotein $\mathrm{Ib} / \mathrm{llla}$ inhibitors, that are currently used to treat patients with unstable angina and myocardial infarction, focusing on their pharmacological properties and the clinical evidence supporting their use.
\end{abstract}

\section{Keywords}

Antiplatelet agent, acute coronary syndromes, antithrombotic, anti-inflammatory, aspirin, $\mathrm{P}_{2} \mathrm{Y}_{12}$ receptor antagonist, glycoprotein IIb/Illa inhibitors

Disclosure: The authors have no conflicts of interest to declare

Received: 29 November 2016 Accepted: 18 January 2017 Citation: European Cardiology Review 2017;12(1):33-7. DOI: 10.15420/ecr.2016:34:2

Correspondence: Albert Ferro, Department of Clinical Pharmacology, Cardiovascular Division, King's College London, Franklin-Wilkins Building, 150 Stamford Street, London SE1 9NH, UK. E: albert.ferro@kcl.ac.uk

Acute coronary syndrome (ACS) is a term used to encompass unstable angina (UA) and myocardial infarction (MI) with or without electrocardiographic (ECG) evidence of ST-segment elevation. Antiplatelet therapy has formed the backbone of ACS management for decades and the drug class continues to evolve as novel agents with increasingly efficacious antiplatelet actions are identified. The main risk associated with all antiplatelet therapies is bleeding, and physicians need to carefully weigh the possible adverse effects against the benefits of prescribing these drugs to patients with ACS. Aspirin, which has been recognised to have antithrombotic effects since the 1960s, continues to be prescribed almost ubiquitously for patients with ACS, and P2Y ${ }_{12}$ antagonists are now often added in; such dual antiplatelet therapy confers greater antithrombotic efficacy but at the risk of increased bleeding. Over recent years, it has become apparent that these drugs may also exert powerful anti-inflammatory effects that provide additional benefit in the management of ACS. This review will discuss antiplatelet agents that are currently used to treat patients with UA and MI.

\section{Aspirin in Acute Coronary Syndrome}

Alongside its analgesic and antipyretic effects, aspirin has been recognised as an inhibitor of platelet function for around 50 years ${ }^{1}$ and, to date, remains the most commonly prescribed drug worldwide. ${ }^{2}$ Current guidelines for the treatment of ACS recommend that all patients routinely receive a loading dose of aspirin, followed by maintenance therapy unless contraindicated. ${ }^{3,4}$ There is a wide range of maintenance dosages of aspirin that are prescribed in this context, ranging from 75 to $325 \mathrm{mg}$ daily in different countries. ${ }^{5}$ In patients who have suffered a Ml, recommended secondary prevention therapy typically entails 12 months of dual antiplatelet therapy, followed by lifelong aspirin, whilst patients with angina (stable or unstable) commence aspirin monotherapy.., 7
The cyclooxygenase (COX) enzyme converts arachidonic acid to prostaglandins. There are two human isoforms: COX-1, which is expressed in most tissues and COX-2, which is typically present in areas of active inflammation but can also (like COX-1) be expressed constitutively in some tissues. ${ }^{8}$ Prostaglandins are a large subgroup of eicosanoids; of these, two derivatives, prostacyclin and thromboxane $\mathrm{A}_{2}$ $\left(\mathrm{TXA}_{2}\right)$, are of particular importance in maintaining platelet homeostasis. Prostacyclin inhibits while TXA $\mathrm{A}_{2}$ increases platelet activation. Aspirin irreversibly inhibits both COX enzymes through acetylation of a critical serine residue, although its effect on COX-1 is at least tenfold greater than that on COX-2. ${ }^{8}$ By predominantly inhibiting COX-1, TXA ${ }_{2}^{-}$ induced platelet activation and aggregation are blocked. ${ }^{9}$ Circulating platelets have a lifespan of 8-10 days, and are typically present at a concentration of $150-400 \times 10^{9}$ per litre of blood (see Figure 1 and Table 1). ${ }^{10}$ Aspirin achieves maximum platelet inhibition within 2 hours following a loading dose and inhibits aggregation in $50 \%$ of circulating platelets for at least five days.11,12 There has been some debate over the past decade as to whether aspirin resistance is a clinically significant issue, requiring patients deemed to be 'poor responders' to switch to an alternative antiplatelet agent.13,14 It has since been shown that whilst platelet function assays may produce variable results, and thus suggest that aspirin resistance is present, platelet COX-1 activity, as reflected by TXA $\mathrm{A}_{2}$ levels, is uniformly and persistently suppressed by low-dose aspirin ${ }^{15}$ and it is now generally accepted that true pharmacological resistance to aspirin is rare. ${ }^{16}$

Data from one of the first large-scale randomised controlled studies assessing the effectiveness of aspirin as an antithrombotic agent were published in $1983-1,266$ men with UA received treatment with either aspirin or placebo, with results showing a significant reduction in progression to $\mathrm{Ml}$ among those taking aspirin. ${ }^{17}$ Aspirin in the setting of acute $\mathrm{Ml}$ has subsequently been found to have 
major beneficial effects on morbidity and mortality, ${ }_{1}^{18,19}$ and multiple meta-analyses have confirmed the pivotal role that aspirin plays in reducing cardiovascular events and mortality in patients with ACS. ${ }^{20,21}$

\section{Adenosine Diphosphate Receptor Antagonists in Acute Coronary Syndrome}

Alongside aspirin therapy, patients with UA or non-ST-elevation MI (NSTEMI) who are considered to have a predicted 6-month mortality of $>1.5 \%$ (which is the case for the vast majority of such patients), are typically treated with a loading dose of $300 \mathrm{mg}$ clopidogrel. ${ }^{22}$ Those with acute ST-elevation MIS (STEMIS) will go on to receive coronary reperfusion therapy, usually with percutaneous coronary intervention (PCl) but more rarely these days with fibrinolytic therapy, and also receive a second antiplatelet agent, namely clopidogrel, prasugrel or ticagrelor depending on local guidelines.

Clopidogrel, prasugrel and ticagrelor are all adenosine diphosphate (ADP) antagonists, a class of therapeutic agents that bind selectively to the $P 2 Y_{12}$ receptor to inhibit platelet function (see Figure 1 and Table 1). ${ }^{23}$ The thienopyridine, ticlopidine was the first drug in this class but is seldom prescribed now, following reports of serious adverse reactions, in particular neutropaenia ${ }^{24}$ and thrombotic thrombocytopaenic purpura. ${ }^{25}$

\section{Clopidogrel}

The second generation thienopyridine prodrug, clopidogrel, is currently the most commonly prescribed ADP receptor antagonist. It is administered orally and up to $85 \%$ of the absorbed drug undergoes hepatic metabolism by carboxylesterases to form an inactive carboxylic acid derivative, clopidogrelic acid, whilst the remaining $15 \%$ is metabolised into the active thiol product by cytochrome P450 isoenzymes. ${ }^{23,26}$ Although clopidogrel has a relatively short half-life of 6 hours, ${ }^{27}$ the thiol metabolite covalently binds to the $\mathrm{P}_{2} \mathrm{Y}_{12}$ receptor, inducing an irreversible conformational change in the receptor and thus impairing thrombotic function for the remaining lifespan of the affected platelet. Genetic polymorphisms in cytochrome P450 enzymes, particularly CYP2C19 and CYP2C9, may result in impaired generation of the active thiol metabolite in patients taking clopidogrel, resulting in lack of efficacy. ${ }^{28}$ Variable responses to clopidogrel may additionally result from mutations in the $A B C B 1$ gene that encodes the P-glycoprotein involved in clopidogrel absorption. ${ }^{28}$

The standard dosing regime is a $300 \mathrm{mg}$ loading dose and $75 \mathrm{mg}$ daily maintenance dose. Following this, steady state ADP inhibition is typically achieved within 3-7 days, with a 40-60\% reduction in ADPinduced platelet aggregation from baseline. ${ }^{27}$ Randomised controlled trials have demonstrated that clopidogrel is more effective than aspirin in preventing cardiovascular events in patients with vascular disease, ${ }^{29}$ reduces mortality further in patients with $\mathrm{Ml}$ when used alongside aspirin, ${ }^{30}$ and improves outcomes in patients undergoing $\mathrm{PCl}$ again when used in combination with aspirin. ${ }^{31,32}$ The Clopidogrel versus Aspirin in Patients at Risk of Ischaemic Events (CAPRIE) study showed that clopidogrel administration was associated with similar adverse effects to those observed with aspirin, including gastrointestinal discomfort and increased bleeding, but the overall safety profile of clopidogrel $75 \mathrm{mg}$ daily was considered to be at least as good as that of aspirin $325 \mathrm{mg}$ daily. ${ }^{29}$ However, the inter-patient unpredictability in clopidogrel responsiveness (with some patients not responding at all) due to the above factors led to the development of newer $\mathrm{P} 2 \mathrm{Y}_{12}$ antagonists.

\section{Prasugrel}

Prasugrel is an oral thienopyridine prodrug that is hydrolysed by esterases to the metabolite, R-95913. This inactive metabolite is then activated by cytochrome P450 enzymes, forming the active metabolite $\mathrm{R}-138727$. As with clopidogrel, the active metabolite subsequently binds irreversibly via a covalent bond to the platelet $\mathrm{P}_{2} \mathrm{Y}_{12}$ receptor and thus inhibits platelet function. ${ }^{33}$

A loading dose of $60 \mathrm{mg}$ is given, followed by $5-10 \mathrm{mg}$ daily maintenance dosing. ${ }^{34}$ Peak plasma concentration is reached within 30 minutes and the drug has a half-life of 7 hours. ${ }^{33}$ Phase I and || studies have demonstrated that prasugrel has a faster onset of action than clopidogrel, as well as being more efficacious and more predictable in its antiplatelet action. ${ }^{35-37}$ The Trial to Assess Improvement in Therapeutic Outcomes by Optimizing Platelet Inhibition with Prasugrel-Thrombolysis in Myocardial Infarction (TRITON-TIMI) 38 phase III study found that in patients with ACS undergoing $\mathrm{PCl}$, prasugrel was more effective than clopidogrel in reducing further ischaemic events although it conveyed a higher risk of major bleeding. ${ }^{38}$ Further analysis of a subgroup of patients with STEMI undergoing PCl found that prasugrel was more effective than clopidogrel in preventing additional cardiovascular events without any increased risk of minor or major bleeding. ${ }^{39}$ Among patients with ACS without ST-elevation who did not undergo PCl, prasugrel was not found to be superior to clopidogrel in preventing ischaemic events..$^{40}$

\section{Ticagrelor}

Unlike clopidogrel and prasugrel, ticagrelor is a cyclopentyl-triazolopyrimidine ADP antagonist and has distinct pharmacokinetic and pharmacodynamic properties. Ticagrelor binds directly to the P2Y ${ }_{12}$ receptor and alters its conformation, resulting in reversible inhibition. The drug does not require metabolic activation and thus exhibits a comparatively rapid onset and offset of effect, necessitating comparatively frequent dosing to achieve steady state ADP inhibition. ${ }^{41}$ Plasma levels of ticagrelor peak at 1.5-3.0 hours post-ingestion and reach steady state after 2-3 days. ${ }^{42}$ Although metabolic activation is not required for initiation of its antiplatelet effects, the drug does have an active metabolite, AR-C124910XX, which is produced following the interaction of the parent drug with cytochrome P450.41,42

Ticagrelor is administered as a loading dose of $180 \mathrm{mg}$, followed by maintenance dosing of either 60 or $90 \mathrm{mg}$ twice daily. The Platelet Inhibition and Patient Outcomes (PLATO) study showed that ticagrelor was superior to clopidogrel in reducing mortality and further cardiovascular events in patients presenting with ACS, regardless of the presence or absence of CYP2C19 and CYP2C9 polymorphisms. ${ }^{43}$ The Dose Confirmation Study Assessing Anti-platelet Effects of AZD6140 versus Clopidogrel in Non-ST-Segment Elevation Myocardial Infarction-2 (DISPERSE-2) showed that there was no increase in major bleeding events in patients with non-ST segment ACS taking ticagrelor compared to clopidogrel; however, there were significantly more minor bleeding events. ${ }^{44}$ Ticagrelor achieves higher levels of platelet inhibition than clopidogrel, ${ }^{45}$ likely due to a combination of factors, including the aforementioned genetic variations in absorption and metabolism of clopidogrel.

In view of the greater platelet inhibition and consequent improved outcomes that are observed with prasugrel and ticagrelor compared with clopidogrel, many cardiology centres now recommend that the latter is not used as a first-line $\mathrm{P}_{2} \mathrm{Y}_{12}$ inhibitor in the management of acute STEMI. ${ }^{46}$ 


\section{Cangrelor}

Cangrelor is a novel P2Y $\mathrm{Y}_{12}$ inhibitor that, like ticagrelor, binds directly to the receptor and induces reversible blockade. The drug is a nonthienopyridine adenosine triphosphate analogue that is administered intravenously and has shown promising results in clinical trials to date. ${ }^{47}$ The drug has a rapid onset and offset of action, reaches steady state within a few minutes and achieves greater than $90 \%$ inhibition of platelet activation resulting from the $\mathrm{P}_{2} \mathrm{Y}_{12}$ pathway. ${ }^{48}$

In a series of randomised controlled studies, when compared with current standard therapy, no significant differences in mortality or further Ml were observed when patients were treated with either clopidogrel or cangrelor before ${ }^{49}$ or during $\mathrm{PCl}^{50} \mathrm{~A}$ double-blind placebo-controlled trial involving 11,145 patients subsequently found that cangrelor significantly reduced the rate of ischaemic events during $\mathrm{PCl}$, with no increase in severe bleeding, compared with clopidogrel. ${ }^{51} \mathrm{At}$ present, cangrelor has been approved by US and European regulatory agencies for use in patients undergoing $\mathrm{PCl}$, although it has not yet been recommended by the National Institute for Health and Care Excellence (NICE) for use in the UK due to a relative lack of clear data. 52,53

\section{Glycoprotein IIb/IIIa Inhibitors in Acute Coronary Syndrome}

The platelet integrin complex glycoprotein (GP) IIb/IIla represents the final common pathway of platelet activation. ${ }^{54,55}$ This molecule mediates platelet adhesion via binding to fibrinogen thereby forming bridges between platelets. A haemostatic platelet plug subsequently develops, which increases in size as further platelet activation is propagated. ${ }^{54}$ GP Ilb/lla receptor inhibitors block this pathway and thus reduce thrombogenesis. Of the drugs in this class, abciximab (a monoclonal antibody fragment), tirofiban (a small, non-peptide molecule) and eptifibatide (a cyclic heptapeptide derived from rattlesnake venom) are used in clinical practice. ${ }^{55,56} \mathrm{Abciximab}$ additionally binds to integrin receptors on leucocytes and endothelial cells, thus reducing the adhesion of platelets to these cells. ${ }^{56}$

GP IIb/IIla inhibitors have played varying roles as antiplatelet agents over the past 20 years. ${ }^{55}$ Data from several large-scale meta-analyses looking at GP IIb/IIla inhibitor clinical trials in the medical management of non-ST-elevation ACS indicate a significant reduction in further MI and overall mortality in patients treated with these agents, ${ }^{57,58}$ and although they were formerly used as key therapies in the management of acute MI for several years, GP IIb/IIla inhibitors have been gradually phased out in favour of the $P 2 Y_{12}$ inhibitors.

A similar trend has followed with regard to the use of GP IIb/IIla inhibitors as prophylactic antithrombotic agents in patients undergoing $\mathrm{PCl}$, where their use has been declining in favour of novel antithrombotic/ anticoagulant drugs. The TRITON-TIMI 38 study found that prasugrel significantly reduced the risk of cardiovascular events in patients with ACS after PCl regardless of whether or not a GP IIb/Illa inhibitor was used concurrently. ${ }^{59}$ The Intracoronary Stenting and Antithrombotic Regimen-Rapid Early Action for Coronary Treatment (ISAR-REACT) trial enrolled 2,159 patients with coronary artery disease who underwent elective $\mathrm{PCl}$ following pre-treatment with clopidogrel $600 \mathrm{mg}$ and either abciximab or placebo; there was no observable clinical benefit in those receiving abciximab over the 30 days post-procedure. ${ }^{60}$ The ISAR-REACT 2 study subsequently assessed 2,022 patients with UA or NSTEMI undergoing PCI who were pre-treated with $600 \mathrm{mg}$ clopidogrel and either abciximab or placebo, and found that abciximab significantly
Figure 1: Sites of Action for Antiplatelet Agents

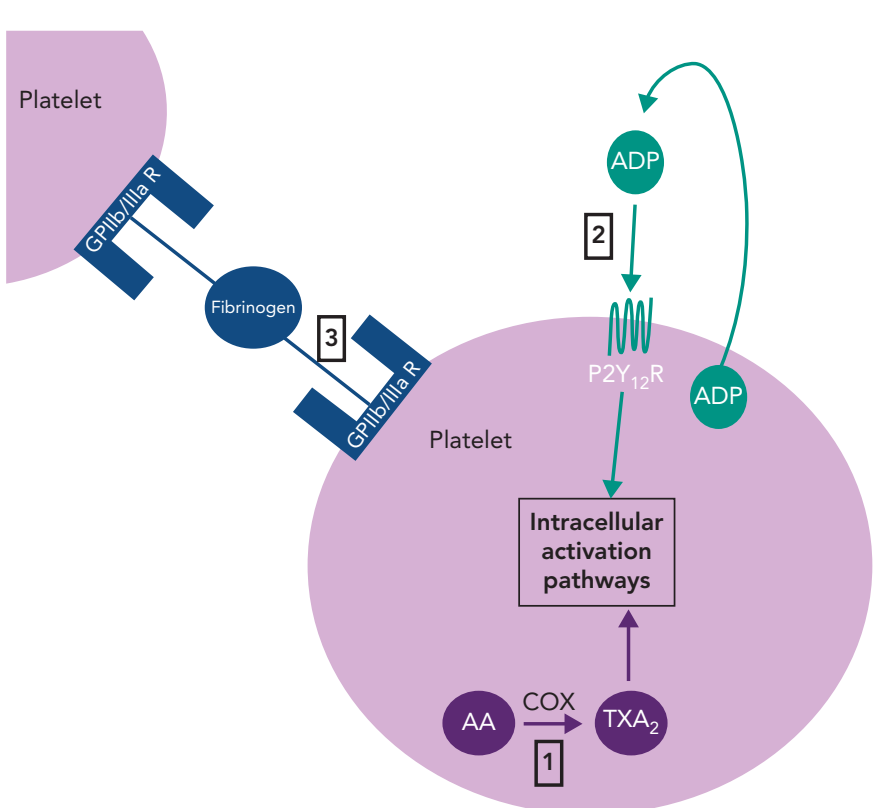

This figure shows the pathways that are interrupted by antiplatelet drugs to impair platelet activation and aggregation. 1: Aspirin acts to inhibit the activity of the cyclooxygenase enzyme and thus attenuates the production of prostaglandins and thromboxane. 2: The ADP receptor antagonists bind to the $P 2 Y_{12}$ receptor to prevent $A D P$-induced platelet activation. 3: Glycoprotein IIb/IIla inhibitors impair platelet adhesion by preventing the formation of fibrinogen bridges between platelets. $A A=$ arachidonic acid; $A D P=$ adenosine diphosphate; COX = cyclooxygenase; $G P=$ glycoprotein; $T X A_{2}=$ thromboxane $A_{2}$.

reduced the incidence of adverse events, although only in those patients with elevated troponin levels at presentation. ${ }^{61}$ In the UK, current NICE guidance recommends GP IIb/IIla inhibitors as an adjunct to $\mathrm{PCl}$ for all patients with diabetes undergoing elective $\mathrm{PCl}$, and for those patients undergoing complex procedures, but not for the routine management of ACS or $\mathrm{PCl}^{62}$

\section{Anti-inflammatory Effects of Antiplatelet Drugs: Possible Relevance to Acute Coronary Syndrome}

In addition to their antiplatelet effects, it has become increasingly recognised that aspirin and the ADP receptor antagonists also exhibit beneficial anti-inflammatory effects in the context of ACS. The Justification for the Use of Statins in Primary Prevention: An Intervention Trial Evaluating Rosuvastatin (JUPITER) identified that elevated levels of high-sensitivity C-reactive protein (hSCRP), a hepatically synthesised biomarker of inflammation produced in response to macrophagederived interleukin-6, were associated with cardiovascular events including $\mathrm{Ml}$ and stroke in patients with no known cardiac disease. ${ }^{63,64}$ HSCRP was found to be a stronger predictor of events than the traditionally used low-density lipoprotein levels, demonstrating the importance of underlying inflammation in the development of atherosclerosis.

Pro-inflammatory biomarkers have been shown to have significant prognostic value in STEMI, ${ }^{65}$ and a recent clinical trial has also identified a potential benefit of an anti-inflammatory therapy (colchicine) in the management of STEMI. ${ }^{66}$ Furthermore, levels of pro-inflammatory CD14 high CD16+ monocytes are also associated with ACS, and a multitude of clinical studies have highlighted the association between raised levels of CD16+ monocytes and coronary disease. CD16+ monocyte counts are elevated in patients with UA compared with matched control subjects with stable coronary artery disease and, among the UA patients, those with intermediate-high risk of MI had significantly higher counts of the 
Table 1: Pharmacological Properties of the Antiplatelet Drugs Discussed in this Review

\begin{tabular}{|c|c|c|c|c|c|}
\hline Drug & Site of Action & Time to Peak Action & Half-life & Typical Dose Administered & Route/Dosing Interval \\
\hline Aspirin & $\begin{array}{l}\text { Inhibition of COX } \\
\text { enzyme }\end{array}$ & $1-2$ hours & $15-20 \mathrm{~min}$ & $\begin{array}{l}\text { In Europe loading dose } 300 \text { mg, } \\
\text { maintenance dose } 75 \text { mg }\end{array}$ & $\begin{array}{l}\text { Oral } \\
\text { Once daily }\end{array}$ \\
\hline Clopidogrel & $\begin{array}{l}\text { Thienopyridine } \\
\text { prodrug irreversibly } \\
\text { binds to the } \mathrm{P}_{2} \mathrm{Y}_{12} \\
\text { receptor }\end{array}$ & $45 \mathrm{~min}$ & 6 hours & $\begin{array}{l}\text { Loading dose } 300-600 \mathrm{mg} \text {, } \\
\text { maintenance dose } 75 \mathrm{mg}\end{array}$ & $\begin{array}{l}\text { Oral } \\
\text { Once daily }\end{array}$ \\
\hline Prasugrel & $\begin{array}{l}\text { Thienopyridine } \\
\text { prodrug, irreversibly } \\
\text { binds to the } \mathrm{P} 2 \mathrm{Y}_{12} \\
\text { receptor }\end{array}$ & $30 \mathrm{~min}$ & 7 hours & $\begin{array}{l}\text { Loading dose } 60 \mathrm{mg}, \\
\text { maintenance dose } 10 \mathrm{mg}\end{array}$ & $\begin{array}{l}\text { Oral } \\
\text { Once daily }\end{array}$ \\
\hline Ticagrelor & $\begin{array}{l}\text { Cyclopentyl-triazolo- } \\
\text { pyrimidine drug, } \\
\text { reversibly binds to } \\
\text { P2Y }_{12} \text { receptor }\end{array}$ & 1.5 hours & 7 hours & $\begin{array}{l}\text { Loading dose } 180 \mathrm{mg}, \\
\text { maintenance dose } 90 \mathrm{mg}\end{array}$ & $\begin{array}{l}\text { Oral } \\
\text { Twice daily }\end{array}$ \\
\hline Cangrelor & $\begin{array}{l}\text { Adenosine triphosphate } \\
\text { analogue, reversibly } \\
\text { binds to } \mathrm{P}_{2} \mathrm{Y}_{12} \text { receptor }\end{array}$ & $2 \min$ & $3-6 \min$ & $\begin{array}{l}\text { Bolus } 30 \mathrm{mcg} / \mathrm{kg} \text { injection } \\
\text { then } 4 \mathrm{mcg} / \mathrm{kg} / \mathrm{min} \text { infusion }\end{array}$ & $\begin{array}{l}\text { Intravenous } \\
\text { One-off treatment }\end{array}$ \\
\hline Abciximab & $\begin{array}{l}\text { Glycoprotein IIb/IIla } \\
\text { receptor inhibitor }\end{array}$ & $30 \mathrm{~min}$ & $30 \mathrm{~min}$ & $\begin{array}{l}\text { Bolus } 0.25 \mathrm{mg} / \mathrm{kg} \text { injection } \\
\text { then } 0.125 \mathrm{mcg} / \mathrm{kg} / \mathrm{min} \\
\text { infusion }\end{array}$ & $\begin{array}{l}\text { Intravenous } \\
\text { One-off treatment }\end{array}$ \\
\hline
\end{tabular}

cox = cyclooxygenase.

CD14 high CD16 monocyte subset. ${ }^{67}$ Tapp et al. found a correlation between CD14 ${ }^{\text {high }}$ CD16+ counts and peak troponin-T levels post-STEMI, as well as a correlation between CD14high CD16+ counts and left ventricular ejection fraction post STEMI. ${ }^{68} \mathrm{~A}$ study of 951 patients referred for elective coronary angiography showed that a higher CD14 highCD16+ count was predictive of cardiovascular events including $\mathrm{MI}$, ischaemic stroke and death from cardiovascular causes. ${ }^{69}$ It has been demonstrated that both aspirin and clopidogrel exert immunomodulatory effects and are capable of counteracting the CD14 high CD16+ monocyte increase that occurs in vivo under pro-inflammatory conditions, ${ }^{70}$ suggesting a potential role for these drugs in reducing monocytic biomarkers of inflammation in patients with cardiovascular disease and possibly thereby improving outcomes further in ACS.

\section{Conclusion}

Coronary artery disease and its related pathologies remain the leading cause of death worldwide. Antiplatelet agents have been used for decades to improve outcomes in patients with ACS and may do so not only through their antithrombotic properties but also through their anti-inflammatory effects, although their relative contribution in this context remains a subject of debate. What is clear, however, is that increased antithrombotic efficacy improves outcomes post-ACS, but carries the price of increased bleeding risk, so that at some point diminishing returns accrue from ever more efficacious antiplatelet therapy. The challenge for the future is to better predict the benefit:risk ratio in individual patients, so that the intensity of antiplatelet therapy can be optimised on a personalised basis.
1. Weiss $\mathrm{HJ}$, Aledort LM. Impaired platelet-connective-tissue reaction in man after aspirin ingestion. Lancet 1967;2:495-7. PMID: 4166411

2. Peterson GM, Jackson SL. Cost-effectiveness of newer antiplatelet drugs. Arch Intern Med 2003;163:2533-4; author reply 2534. DOI: 10.1001/archinte.163.20.2533-b; PMID: 14609794

3. Alifano M, Roth T, Broët SC, et al. Catamenial pneumothorax: a prospective study. Chest 2003;124(3):1004-8. PMID: a prospective

4. Joseph J, Sahn SA. Thoracic endometriosis syndrome: new observations from an analysis of 110 cases. Am J Med 1996;100:164-70. PMID: 8629650

5. Lacasse $Y$, Girard M, Cormier Y. Recent advances in hypersensitivity pneumonitis. Chest 2012;142:208-17. DOI: 10.1378/chest.11-2479; PMID: 22796841

6. Centre for Disease Control, Flu and Heart Disease \& Stroke. Available at: www.cdc.gov/flu/heartdisease (Accessed 7 May 2016).

National Health Service, who should have the flu jab? Available at: www.nhs.uk/conditions/vaccinations/pages/ Avallable at: www.nhs.uk/conditions/vaccinations/pages/

8. Carașca C, Borda A, Incze A, et al. Limb ischemia, an alarm signal to a thromboembolic cascade - renal infarction and nephrectomy followed by surgical suppression of the left atrial appendage. Rom I Morphol Embryol 2016;57:547-50. PMID: 27516032

9. Muhlestein JB. Effect of antiplatelet therapy on inflammatory markers in atherothrombotic patients. Thromb Haemost 2010;103:71-82. DOI: 10.1160/TH09-03-0177; PMID: 20062914

10. Leeksma CHW, Cohen JA. Determination of the life span of human blood platelets using labelled diisopropylfluorophosphonate. I Clin Invest 1956;35: 964-9. DOI: 10.1172/JCI103356; PMCID: PMC441670

11. Jneid $H, B$ Batt $D L$, Corti $R$, et al. Aspirin and clopidogrel in acute coronary syndromes: therapeutic insights from the
CURE study. Arch Intern Med 2003;163:1145-53. DOI: 10.1001/ archinte.163.10.1145; PMID: 12767950

12. Maree AO, Fitzgerald DJ. Variable platelet response to aspirin and clopidogrel in atherothrombotic disease. Circulation 2007;115:2196-207. DOI: 10.1161/ CIRCULATIONAHA.106.675991; PMID: 17452618

13. Pamukcu B, Oflaz $\mathrm{H}$, Oncul A, et al. The role of aspirin resistance on outcome in patients with acute coronary syndrome and the effect of clopidogrel therapy in the prevention of major the effect of clopidogrel therapy in the prevention of major cardiovascular events. J Thromb Thrombolysis 2006;22:
DOI: 10.1007/s11239-006-8952-4; PMID: 17008975

14. Gum PA, Kottke-Marchant $K$, Welsh PA, et al. A prospective, blinded determination of the natural history of aspirin resistance among stable patients with cardiovascular disease. J Am Coll Cardiol 2003;41:961-5. PMID: 12651041

15. Santilli F, Rocca B, De Cristofaro R, et al. Platelet cyclooxygenase inhibition by low-dose aspirin is not reflected consistently by platelet function assays: implications for aspirin "resistance". J Am Coll Cardiol 2009;53:667-77. DOI: 10.1016/j.jacc.2008.10.047; PMID: 19232899

16. Grosser T, Fries S, Lawson JA, et al. Drug resistance and pseudoresistance: an unintended consequence of enteric coating aspirin. Circulation 2013;127:377-85. DOI: 10.1161/ CIRCULATIONAHA.112.117283; PMID: 23212718; PMCID: PMC3552520

17. Lewis HD Jr, Davis JW, Archibald DG, et al. Protective effects of aspirin against acute myocardial infarction and death in men with unstable angina. Results of a Veterans Administration Cooperative Study. N Eng/ J Med 1983;309:396-403. DOI: 10.1056/NEJM198308183090703: PMID: 6135989

18. Randomised trial of intravenous streptokinase, oral aspirin both, or neither among 17,187 cases of suspected acute myocardial infarction: ISIS-2. ISIS-2 (Second International Study of Infarct Survival) Collaborative Group. Lancet 1988;2(8607):349-60. PMID: 2899772

19. Fuster V, Dyken ML, Vokonas PS, Hennekens C. Aspirin as a therapeutic agent in cardiovascular disease. Special Writing Group. Circulation 1993;87:659-75. PMID: 8425313

20. Antithrombotic Trialists' (ATT) Collaboration, Baigent $C$ Blackwell $L$, Collins R, et al. Aspirin in the primary and secondary prevention of vascular disease: collaborative meta-analysis of individual participant data from randomised trials. Lancet 2009;373:1849-60. DOI: 10.1016/S01406736(09)60503-1; PMID: 19482214; PMCID: PMC2715005

21. Collaborative overview of randomised trials of antiplatelet therapy--I: Prevention of death, myocardial infarction, and stroke by prolonged antiplatelet therapy in various and stroke by prolonged antiplatelet therapy in various
categories of patients. Antiplatelet Trialists' Collaboration. BMJ 1994;308:81-106. PMID: 8298418; PMCID: PMC2539220

22. Lepur D, Klinar I, Mise B, et al. McKittrick-Wheelock syndrome: a rare cause of diarrhoea. Eur J Gastroenterol Hepatol 2006;18:557-9. PMID: 16607156

23. Zaid AN, Al Ramahi R, Bustami R, et al. Comparative fasting bioavailability of two clopidogrel formulations in healthy Mediterranean volunteers: an in vitro-in vivo correlation. Drug Des Devel Ther 2015;9:2359-65. DOI: 10.2147/DDDT.S78658; Des Devel Ther 2015;9:2359-65. DOI: 10.2147
PMID: 25987833; PMCID: PMC4422294

24. Ono K, Kurohara K, Yoshihara M, et al. Agranulocytosis caused by ticlopidine and its mechanism. Am J Hematol 1991;37:239-42. PMID: 1858780

25. K Kovacs MJ, Soong PY, Chin-Yee $\mathbb{H}$. Thrombotic thrombocytopenic purpura associated with ticlopidine. Ann Pharmacother 1993;27:1060-1. PMID: 8219438

26. Wijeyeratne YD, Heptinstall S. Anti-platelet therapy: ADP receptor antagonists. Br J Clin Pharmacol 2011;72:647-57. DOI: 10.1111/1.1365-2125.2011.03999.x; PMCID: PMC3187865

27. Marks M, Mangera Z, Cervi P. Thrombotic thrombocytopenic purpura in a patient with HIV from Zimbabwe. BMJ Case Rep 2009; 2009:pii: bcr05.2009.1854. DOI: 10.1136/ bcr.05.2009.1854; PMID: 21822450; PMCID: PMC3028006

28. Kubica A, Kozinski M, Grzesk G, et al. Genetic determinants of platelet response to clopidogrel. I Thromb Thrombolysis 
2011:32:459-66. DOI: 10.1007/S11239-011-0611-8; PMID: 21706290: PMCID: PMC3181405

29. CAPRIE Steering Committee. A randomised, blinded, trial of clopidogrel versus aspirin in patients at risk of ischaemic events (CAPRIE). CAPRIE Steering Committee. Lancet 1996;348:1329-39. PMID: 8918275

30. Chen ZM, Jiang LX, Chen YP, et al. Addition of clopidogrel to aspirin in 45,852 patients with acute myocardial infarction: randomised placebo-controlled trial. Lancet 2005;366:1607-21. DOI: 10.1016/S0140-6736(05)67660-X; PMID: 16271642

31. Sabatine MS, Hamdalla HN, Mehta SR, et al. Efficacy and safety of clopidogrel pretreatment before percutaneous coronary intervention with and without glycoprotein IIb/ Illa inhibitor use. Am Heart J 2008;155:910-7. DOI: 10.1016/j. ahj.2007.11.020; PMID: 18440341

32. Sabatine MS, Cannon CP, Gibson CM, et al. Effect of clopidogrel pretreatment before percutaneous coronary intervention in patients with ST-elevation myocardial infarction treated with fibrinolytics: the PCI-CLARITY study. JAMA 2005;294:1224-32. DOI: 10.1001/jama.294.10.1224; PMID: 16143698

33. Wiviott $S D$, Antman EM, Braunwald E. Prasugrel. Circulation 2010;122:394-403. DOI: 10.1161/ CIRCULATIONAHA. 109.921502; PMID: 20660815

34. Findik S. Pleural effusion in pulmonary embolism. Curr Opin Pulm Med 2012;18:347-54. DOI: 10.1097/ MCP.0b013e32835395d5; PMID: 22498732

35. Light RW. Pleural effusion due to pulmonary emboli. Curr opin Pulm Med 2001;7:198-201. PMID: 11470974

36. Brandt JT, Payne CD, Wiviott SD, et al. A comparison of prasugrel and clopidogrel loading doses on platelet function: magnitude of platelet inhibition is related to active metabolite formation. Am Heart J 2007;153:66.e9-16. DOI: 10.1016/j. formation. Am Heart I 2007;153:66.e

37. Wiviott SD, Trenk D, Frelinger AL, et al. Prasugrel compared with high loading- and maintenance-dose clopidogrel in patients with planned percutaneous coronary intervention: the Prasugrel in Comparison to Clopidogrel for Inhibition of Platelet Activation and Aggregation-Thrombolysis in Myocardial Infarction 44 trial. Circulation 2007;116:2923-32. DOI: 10.1161/CIRCULATIONAHA.107.740324; PMID: 18056526

38. Wiviott $\mathrm{SD}$, Braunwald $\mathrm{E}$, McCabe $\mathrm{CH}$, et al. Prasugrel versus clopidogrel in patients with acute coronary syndromes. N Eng Clopidogrel in patients with acute coronary syndromes. NEng J Med 2007

39. Montalescot G, Wiviott SD, Braunwald E, et al. Prasugrel compared with clopidogrel in patients undergoing percutaneous coronary intervention for ST-elevation myocardial infarction (TRITON-TIMI 38): double-blind, randomised controlled trial. Lancet 2009;373:723-31. DOI: 10.1016/S0140-6736(09)60441-4; PMID: 19249633

40. Roe MT, Armstrong PW, Fox KA, et al. Prasugrel versus clopidogrel for acute coronary syndromes without revascularization. N Engl I Med 2012;367:1297-309. DO 10.1056/NEJMoa1205512; PMID: 22920930

41. Husted S, van Giezen JJ. Ticagrelor: the first reversibly binding oral P2Y12 receptor antagonist. Cardiovasc Ther 2009;27:259-74. DOI:10.1111/j.1755-5922.2009.00096.x; PMID:19604248; PMCID:PMC2948430

42. Dobesh PP, Oestreich JH. Ticagrelor: pharmacokinetics, pharmacodynamics, clinical efficacy, and safety. Pharmacotherapy 2014;34:1077-90. DOl:10.1002/phar.1477; PMID:25164528; PMCID:PMC4282310

43. Wallentin $L$, Becker RC, Budaj $A$, et al. Ticagrelor versus clopidogrel in patients with acute coronary syndromes. $N$
Eng/ I Med 2009:361:1045-57. DOI:10.1056/NEJMoa0904327: PMID:19717846

44. Cannon $\mathrm{CP}$, Husted $\mathrm{S}$, Harrington RA, et al. Safety, tolerability, and initial efficacy of AZD6140, the first reversible oral adenosine diphosphate receptor antagonist, compared with clopidogrel, in patients with non-ST-segment elevation acute coronary syndrome: primary results of the DISPERSE-2 trial. Am Coll Cardiol 2007;50:1844-51. DOI:10.1016/j.jacc.2007.07.053; PMID:17980250

45. Storey RF, Angiolillo DJ, Patil SB, et al. Inhibitory effects of ticagrelor compared with clopidogrel on platelet function in patients with acute coronary syndromes: the PLATO (PLATelet inhibition and patient Outcomes) PLATELET substudy. J Am inhibition and patient Outcomes) PLATELET substudy. J Am
Coll Cardiol 2010;56:1456-62. DOl:10.1016/i.jacc.2010.03.100; Coll Cardiol 2010,56:1
PMID:20832963

46. Kloppenborg RP, Richard E, Sprengers MES, et al. Steroid responsive encephalopathy in cerebral amyloid angiopathy: a case report and review of evidence for immunosuppressive treatment. J Neuroinflammation 2010;7:18. DOI: 10.1186/17422094-7-18; PMCID: PMC2846904

47. Greenbaum $\mathrm{AB}$, Grines $\mathrm{CL}$, Bittl JA, et al. Initial experience with an intravenous $\mathrm{P} 2 \mathrm{Y} 12$ platelet receptor antagonist in patients undergoing percutaneous coronary intervention: results from a 2-part, phase II, multicenter, randomized, placebo- and active-controlled trial. Am Heart J 2006;151:689. e1-689 e10. DOI:10.1016/j.ahj.2005.11.014; PMID:16504633

48. Marcano AL, Ferreiro JL. Role of New Antiplatelet Drugs on Cardiovascular Disease: Update on Cangrelor. Curr Atheroscler Rep 2016;18:66. DOl:10.1007/s11883-016-0617-y; PMID:27714642

49. Harrington RA, Stone GW, MCNulty S, et al. Platelet inhibition with cangrelor in patients undergoing PCl. N Eng J Med 2009;361:2318-29. DOl:10.1056/NEJMOa0908628; PMID:19915221

50. Bhatt DL, Lincoff AM, Gibson CM, et al. Intravenous platelet blockade with cangrelor during PCI. N Engl I Med 2009;361:2330-41. DOI:10.1056/NEJMoa0908629; PMID:19915222

51. Bhatt DL, Stone GW, Mahaffey KW, et al. Effect of platelet inhibition with cangrelor during $\mathrm{PCl}$ on ischemic events. $N$ Engl J Med 2013:368:1303-13. DOI:10.1056/NEJMoa1300815; PMID:23473369

52. Boccardo P, Remuzzi G, Galbusera M. Platelet dysfunction in renal failure. Semin Thromb Hemost 2004:30:579-89. DOl:10.1055/s-2004-835678; PMID:15497100

53. De Luca L, Capranzano P, Patti G, Parodi G. Switching of platelet P2Y12 receptor inhibitors in patients with acute coronary syndromes undergoing percutaneous coronary intervention: Review of the literature and practical considerations. Am Heart J 2016;176:44-52. DOI:10.1016/j. ahj.2016.03.006; PMID:27264219

54. Offermanns $\mathrm{S}$. Activation of platelet function through $\mathrm{G}$ protein-coupled receptors. Circ Res 2006;99:1293-304. Dol:10.1161/01.RES.0000251742.71301.16; PMID:17158345

55. Subban V, Sarat Chandra K. Glycoprotein IIb-Illa inhibitors - do we still need them? Indian Heart J 2013;65:260-3. DOI: 10.1016 j.ihj.2013.04.032; PMCID: PMC3861204

56. Topol EJ, Moliterno DJ, Herrmann HC, et al. Comparison of two platelet glycoprotein IIb/Illa inhibitors, tirofiban and abciximab, for the prevention of ischemic events with percutaneous coronary revascularization. $N$ Eng/ I Med 2001;344:1888-94. DOI:10.1056/NEJM200106213442502; PMID:11419425

57. Roffi M, Chew DP, Mukherjee D, et al. Platelet glycoprotein $\mathrm{Ilb} / \mathrm{lll}$ a inhibition in acute coronary syndromes. Gradient of benefit related to the revascularization strategy. Eur Heart J 2002;23:1441-8. PMID:12208224

58. Boersma E, Harrington RA, Moliterno DJ, et al. Platelet glycoprotein Ilb/llla inhibitors in acute coronary syndromes: a meta-analysis of all major randomised clinical trials. Lancet 2002;359:189-98. DOI:10.1016/S0140-6736(02)07442-1; PMID:11812552

59. O'Donoghue M, Antman EM, Braunwald E, et al. The efficacy and safety of prasugrel with and without a glycoprotein IIb/ Illa inhibitor in patients with acute coronary syndromes undergoing percutaneous intervention: a TRITON-TIMI 38 (Trial to Assess Improvement in Therapeutic Outcomes by Optimizing Platelet Inhibition With Prasugrel-Thrombolysis In Myocardial Infarction 38) analysis. J Am Coll Cardiol 2009;54: 678-85. DOI:10.1016/j.jacc.2009.05.025; PMID:19679245

60. Kastrati A, Mehilli J, Schühlen $H$, et al. A clinical trial of abciximab in elective percutaneous coronary intervention after pretreatment with clopidogrel. N Eng/ J Med 2004;350: 232-8. DOI:10.1056/NEJMoa031859; PMID:14724302

61. Kastrati A, Mehilli J, Neumann FJ, et al. Abciximab in patients with acute coronary syndromes undergoing percutaneous coronary intervention after clopidogrel pretreatment: the ISAR-REACT 2 randomized trial. JAMA 2006;295:1531-8. DOI:10.1001/jama.295.13.joc60034; 2006;295:1531-8
PMID:16533938

62. Mills JA, Michel BA, Bloch DA, et al. The American College of Rheumatology 1990 criteria for the classification of Henoch-Schönlein purpura. Arthritis Rheum 1990;33:1114-21. PMID:2202310

63. Ridker PM. High-sensitivity C-reactive protein and cardiovascular risk: rationale for screening and primary prevention. Am I Cardiol 2003;92:17K-22K. PMID:12948872

64. Ridker PM; JUPITER Study Group. Rosuvastatin in the primary prevention of cardiovascular disease among patients with low levels of low-density lipoprotein cholesterol and elevated high-sensitivity C-reactive protein: rationale and design of the JUPITER trial. Circulation 2003;108:2292-7. DOI:10.1161/01. CIR.0000100688.17280.E6; PMID:14609996

65. van Diepen S, Newby LK, Lopes RD, et al. Prognostic relevance of baseline pro- and anti-inflammatory markers in STEMI: an APEX AMI substudy. Int I Cardiol 2013;168:2127-33. DOI:10.1016/j.jicard.2013.01.004; PMID:23394896

66. Deftereos S, Giannopoulos G, Angelidis C, et al. AntiInflammatory Treatment With Colchicine in Acute Myocardial Infarction: A Pilot Study. Circulation 2015;132:1395-403. DOI:10.1161/CIRCULATIONAHA.115.017611; PMID:26265659

67. Zeng S, Zhou X, Ge L, et al. Monocyte subsets and monocyteplatelet aggregates in patients with unstable angina. $J$ Thromb Thrombolysis 2014;38:439-46. DOI:10.1007/s11239-014-1083-4; PMID:24844803

68. Tapp LD, Shantsila E, Wrigley BJ, et al. The CD14++CD16+ monocyte subset and monocyte-platelet interactions in patients with ST-elevation myocardial infarction. J Thromb Haemost 2012:10:1231-41. DOl:10.1111/j.15387836.2011.04603.x; PMID:22212813

69. Rogacev KS, Cremers B, Zawada AM, et al. CD14++CD16+ monocytes independently predict cardiovascular events: a cohort study of 951 patients referred for elective coronary angiography. J Am Coll Cardiol 2012;60:1512-20. DOI:10.1016/ j.jacc.2012.07.019; PMID:22999728

70. Layne K, Di Giosia P, Ferro A, Passacquale G. Anti-platelet drugs attenuate the expansion of circulating CD14highCD16+ monocytes under pro-inflammatory conditions. Cardiovasc Res 2016;111:26-33. DOl:10.1093/cVr/crw089; PMID:27118470; PMCID.PMC4909161 